\title{
The Application of Pygmalion Effect in Classroom Education
}

\author{
Mengqian Wang \\ College of Language and Cultural Communications \\ Shangluo University \\ Shangluo, China
}

\author{
Jun Cai \\ College of Urban, Rural Planning and Architectural \\ Engineering \\ Shangluo University \\ Shangluo, China
}

\begin{abstract}
The Pygmalion effect is the phenomenon whereby higher expectations lead to an increase in performance. The expectations of teachers showed a very powerful predictive relationship with student behaviour. High expectations of teachers create a better atmosphere for student learning. The Pygmalion effect can influence student achievement and offer the support to help students achieve their goals.
\end{abstract}

Keywords-Pygmalion effect; expectation; classroom education

\section{INTRODUCTION}

The Pygmalion of Greek myth was a sculptor. He carved an ivory statue. The statue was so beautiful that he fell in love with it. The statue came to life and they went on to marry. The Pygmalion effect refers to the phenomenon in which the greater the expectation placed upon students the better they perform. The Pygmalion effect is a type of selffulfilling prophecy where if you think something will happen, you may unconsciously make it happen through your actions or inaction.

Psychological research on Pygmalion effect began with Robert Rosenthal and Lenore Jacobson.

In the classic study "Pygmalion in the Classroom", psychologists Robert Rosenthal and Lenore Jacobson describe an experiment in which certain teachers had been informed that they had exceptionally intelligent students. Robert Rosenthal and Lenore Jacobson conducted an research in which teachers at an elementary school were informed that twenty percent of the students in the school who were showing unusual potential for intellectual growth and they would bloom academically within the year. These students were selected randomly with no relation to the initial test. When the students were tested eight months later, it is discovered that the randomly selected students who teachers thought would bloom scored significantly higher. The studies showed that the expectations of experimenters for their behavior could operate as self-fulfilling prophecies. Self-fulfilling prophecies were first defined by sociologist Robert K. Merton in 1948. The following five-step model explains how the self-fulfilling prophecies work:

- The teacher forms expectations.
- $\quad$ Based upon these expectations, the teacher acts in a differential manner.

- The teacher's treatment tells each student what behavior and what achievement the teacher expects.

- If this treatment is consistent, it will tend to shape the student's behavior and achievement.

- With time, the student's behavior and achievement will conform more and more closely to that expected of him or her.

Experimenters may acquire substantial results because they unintentionally bias participants to respond in the hypothesized manner. Many other studies have been conducted on the Pygmalion effect in the classroom education. It revealed that when teachers have higher expectations of students, they unconsciously give more positive attention, feedback, and learning opportunities to those students. Many psychologists think that teachers actually convey their expectations to their students, even if neither they nor the students ever actually realize it. Body language is as important as verbal communication when conveying both positive and negative expectations. The use of body language can prove to be very powerful. Students tend to act in accordance with the expectation of teachers to fulfill those expectations.

\section{ThE APPLICATION OF PygMALION EFFECT}

In brief, the Pygmalion effect is the idea that if someone is told that they can do better, they will. Many researchers have been studying the Pygmalion effect in many fields. From existing studies, we can outline the way the Pygmalion effect occurs as follows:

- A teacher's high expectation influences his attitude toward his students.

- Such attitude has positive effects on students' selfexpectancy.

- The students' enhanced self-expectancy then improves their performance.

Marva Collins, one of the most extraordinary educators of the 20th century, offers an example of the Pygmalion 
effect in action. Dissatisfied with the Chicago public school system, she decided to open her own school on the second floor of her home in inner-city Chicago. Marva took in learning disabled, problem children and even one child who had been regarded by Chicago public school authorities as borderline retarded. At the end of the first year, every child scored at least five grades higher proving that the previous labels placed on these children were misguided. Marva had them opining about the meaning of justice in modern society. Her belief in the capability of her students became a selffulfilling prophecy that enabled them to achieve extraordinary results.

Research of psychologists shows that the quality of the relationship between teachers and students has a direct impact on students' learning initiative. Teachers character can determine the students like or dislike a subject. In classroom, teachers should make the students enter the best psychological state with a kind, friendly, generous and humorous language. The teachers should communicate their high expectations to their students by providing them with extra verbal and nonverbal reinforcement. Teachers care for students can narrow the distance between teachers and students and eliminate the estrangement between each other. Good relationship between teachers and students can increase students study enthusiasm and improve the learning effect. Teachers should be concerned about the students, so that the classroom teaching can be welcomed by students. The teachers directly and indirectly communicated to their students that they were high achievers, and the students actually came to believe that they were high achievers. In other words, the expectations of their teachers influenced the students' self-concepts.

Students should be encouraged by teachers to eliminate the psychological distance between teachers and students, eliminate the psychological barriers, and believe that each of them has their own strengths.

\section{THE RELATIONSHIP BETWEEN TEACHER EXPECTATIONS AND STUDENT BEHAVIOUR}

It has been proposed that this behaviour alteration is in the percipience of the teacher. Perhaps this alteration happens in the teachers' mentality, and the actual performance of the student remains unchanged. In a study of the relationship between teacher expectations and student behaviour, it is found that the teachers' expectations and students' behaviour had a significant relationship and teacher expectations really forecast student behaviour. There is causal relationship between teacher expectations and student behaviour in classroom. High expectations of teacher create a better atmosphere for student learning.

There is a classification of decisions that affect a teacher's expectations of a student's ability. Some of the most common are test scores, evaluations, gender and so on. For slow students learning, there is an atmosphere in which teachers feel less responsible which influences teacher expectations for individual students. Social psychologists have proved that an individual's first perception of another person influences their following interactions.
In a study of the Pygmalion effect on essay assignments assessments, it is found that there is a Pygmalion Effect for handwriting. The mean score of student essays were handwritten in a legible style was higher than the identical essays written in an illegible style. The illegible handwriting was regarded as a male student, even if written by a female student. The legible handwritings received higher scores and handwriting played an important role for the final scores. It is obvious that something other than the student's ability influenced their scores.It was shown that top students were given more attention, more response opportunity, more feedback, and more consideration by their teacher compared to underachievers.

\section{CONCLUSION}

The study shows that teachers should enhance expectations for students. Teacher instruction capability should be improved and teachers should get more training. The Pygmalion effect can influence student achievement and offer the support to help students achieve their goals.

\section{ACKNOWLEDGEMENT}

This study was financially supported by the Education Teaching Reform Research Project of Shangluo University (Grant NO. 14jyjx112).

\section{REFERENCES}

[1] Lee Jussim, Jacquelynne Eccles, and Stephanie Madon, Social Perception, Social Stereotypes, and Teacher Expectations: Accuracy and the Quest for the Powerful Self-Fulfilling Prophecy, Advances in Experimental Social Psychology, 28 (1996): 281 - 388.

[2] Trouilloud, D.O., Sarrazin, P.G., The influence of teacher expectations on students' achievement in physical education classes: Pygmalion revisited. European Journal of Social Psychology, 32 (2002): 591-607.

[3] Bay, L., Twists, turns and returns: Returning adult students. National Council of Teachers of English, 26(3) (1999): 305-312.

[4] Diamond, J. B., Randolph, A., \& Spillane, J. P. , Teachers expectations and sense of responsibility for student learning: The importance of race, class, and organizational habitus. Anthropology and Education Quarterly, 35 (2004): 75-98.

[5] Lee Jussim and Kent D. Harber, Teacher Expectations and SelfFulfilling Prophesies: Knowns and Unknowns, Resolved and Unresolved Controversies, Personality and Social Psychology Review 9 (2) (2005): 131 - 155.

[6] Fiedler, K., Illusory correlations: A simple associative algorithm provides a convergent account of seemingly divergent paradigms, Review of General Psychology, 4 (2000): 25-58.

[7] Hester De Boer, Roel J. Bosker, and Margaretha P. C. van der Werf, Sustainability of teacher expectation bias effects on long-term student performance, Journal of Educational Psychology 102 (1) (2010): 168 -179 .

[8] Alison E. Smith, Lee Jussim, and Jacquelynne Eccles, Do selffulfilling prophesies accumulate, dissipate, or remain stable over time? Journal of Personality and Social Psychology 77 (3) (1999): 548 565 .

[9] Robinson, S. L., OLeary-Kelly, A. M., Monkey see, monkey do: The influence of work groups on the antisocial behavior. Academy of Management Journal, 41(6) (1998): 658-672. 
[10] Powers, F., Second-career teachers: Perspectives and mission in their new careers. International Studies in Sociology of Education, 12(3) (2002): 62-78

[11] J. Benjamin Hinnant, Marion Brien, and Sharon R. Ghazarian, The Longitudinal Relations of Teacher Expectations to Achievement in the Early School Years, Journal of Educational Psychology, 101 (3) (2009): $662-670$.

[12] Robert T. Tauber, What teachers expect from students, they generally get! Education Matters ,4 (2009): 1 - 5. 